DOI:10.18535/ijahm/v7i6.17

Impact Factor: 4.415

\title{
Yoga For Health And Wellness
}

\author{
Dr. Ravi Shankar Mourya ${ }^{1}$, Dr. Rajveer Gupta ${ }^{2}$, Dr. Omh Prakash Shukla ${ }^{3}$, \\ Dr. Shri Narayan Tiwari ${ }^{4}$ \\ ${ }^{1}$ M.D. Scholar Department of Samhita Siddhant \\ ${ }^{2}$ M.D. Scholar Department of Samhita Siddhant \\ ${ }^{3}$ Assistant Professor Department of Samhita Siddhant \\ ${ }^{4}$ Associate Professor Department of Samhita Siddhant Govt. Auto. Ayurved College Rewa (M.P).
}

\begin{abstract}
:-
Yoga is the most perfect health and wellness module as it is comprehensive and holistic in nature. Yogic principal helps to strengthen and develop positive health enabling us to withstand stress better. This yogic "Health insurance" has achieved by normalizing the perception of stress, effectively through the practice of various Yogic practices. Yoga is a holistic and integral science of life dealing with physical, mental, emotional and spiritual health of an individual and society. Have you ever thought what would life be like if every individual around us is stressed, unhealthy, bound to negative thinking, no enthusiasm and will power? What do you think about peoples who are always ill and unhappy? And actually the today's world is facing the same complications. Various life threatening diseases are increasing at an alarming rate in present era. Leading a healthy life is no easy feat. You may have tried Cardio, Pilates, Aerobics, Gymnastics and other strenuous exercises, but have you ever tried YOGA?

Health and Wellness are closely related to lifestyle of an individual. Lifestyle is the way people live and this has immense influence on the status of health or disease of an individual. Since one's lifestyle has developed early in life, it is advisable to cultivate healthy lifestyle in early childhood. Many factors determine one's lifestyle. Economic status determines incidence of under-nutrition in poor and obesity in the rich.

Now, Yoga is being practiced as an alternative healthcare practice. The number of Yoga practitioners continues to rise tremendously.
\end{abstract}

KEY WORDS:- Health insurance, Life threatening diseases, Stress, Cardio, Pilates, Aerobics, Gymnastics, Yoga.

\section{INTRODUCTION : -}

Yoga is an invaluable gift of India's ancient tradition. It embodies unity of mind and body thought and action; harmony between man and nature; a holistic approach to health and wellbeing. Yoga is not only about exercise but to discover the sense of oneness with yourself, the world and the nature.

\section{CONTEXT OF YOGA:-}

The practice of Yoga is explained in detail in a religious scripture called as "Yoga Sutra" authored by "Sage Patanjali". It also finds references in Rigveda, Jain texts and other religious texts and Puranas.

\section{OBJECTIVE OF YOGA :-}

Yoga is vital for healthy and happy life, how? I tell you we. When do Yoga postures our body gets sufficient stretching and strain. Stretching is the most important for active daily routine.

Secondly, when we do Yoga our blood circulation and pulse rate become normal. Yoga give mental peace.

Yoga aims to help its practitioner attains MOKSHA (Liberation). 
Dr. Ravi Shankar Mourya ${ }^{1}$, International Journal of Ayurvedic\& Herbal Medicine 7(6) Nov.-Dec. 2017 (3030-3033)

$$
\text { Samanya Purusha } \rightarrow \text { Yoga } \rightarrow \text { Uttama Purusha } \rightarrow \text { Daivatwa } \rightarrow \text { Moksha. }
$$

Yoga is an all-round personality development i.e. at physical, mental, intellectual, emotional \& spiritual level. It is a state of consciousness, culturing and controlling of mind.

\section{PERFECT TIMEING FOR YOGA PRACTICE : -}

Most effective timing for doing yoga in Brahma Muhurta (Early morning) with half of the body energy (Ardhabala) in winter \& spring season and less than that in another seasons.

\section{PATHWAYS OF YOGA ASANAS :-}

- GyanYoga:- In this particular type of yoga , the human being knows it's reality by studying spiritual text and by decent utilization of meditation.

$$
\text { Shravan } \rightarrow \text { Manan } \rightarrow \text { Nidhidhyasan } \rightarrow \text { Gyan } \rightarrow \text { Vairagya } \rightarrow \text { Moksha }
$$

- MantraYoga/BhaktiYoga:- It is a specific type of yoga, where the yogi is consistently dedicated about the All Mighty God.

$$
\begin{gathered}
\text { Asuri } \rightarrow \text { Samanya purusha } \rightarrow \text { Mahana purusha } \rightarrow \text { Daiv } \rightarrow \text { Prem } \rightarrow \text { Bhakti } \rightarrow \text { Saguna sakshatkar } \\
\rightarrow \text { Nirguna Samadhi } \rightarrow \text { Moksha. }
\end{gathered}
$$

- KarmaYoga:- It is mainly mentioned about married individual, Who are expected to achieve yoga siddhi performing their routine work. The yogi does not expect the result while performing certain liabilities and duties. This state is considered as a Nishkamkarma Yoga.

$$
\text { Tamas guna } \rightarrow \text { Rajasguna } \rightarrow \text { Satvaguna } \rightarrow \text { Gunatita } \rightarrow \text { Moksha } .
$$

- RajaYoga:- It is believed that Raja yoga is superior to all the other Yogas, It leads to Liberation. "Ashtanga Yoga of Maharishi Patanjali" comes under this RajaYoga.

$$
\begin{aligned}
& \checkmark \text { Yama } \rightarrow \text { Social Health } \\
& \checkmark \text { Niyama \& Pratyahara } \rightarrow \text { Mental Health } \\
& \checkmark \text { Asana \& Pranayama } \rightarrow \text { Physical Health } \\
& \checkmark \text { Dharna \& Dhyana } \rightarrow \text { Spiritual Health } \\
& \checkmark \text { Samadhi } \rightarrow \text { Liberation }
\end{aligned}
$$$$
\text { Yama } \rightarrow \text { Niyama } \rightarrow \text { Asana } \rightarrow \text { Pranayam } \rightarrow \text { Pratyahar } \rightarrow \text { Dharna } \rightarrow \text { Dhyan } \rightarrow \text { Samadhi } \rightarrow
$$
Moksha.

- Hatha Yoga :- Hatha yoga promotes health and prepares an individual for spiritual aspects like Kundalini Jagrana, Dhyan \& Samadhi. It basically works on two principles, i.e, HA (Sun) \& THA (Moon) and brings about balance in between the two.

\section{PANCHKOSHA THEORY :-}

Through practice of Yoga one can know the diseased condition (Rogavastha) of the body by getting the knowledge of PANCHKOSHA.

Panchkosha (i.e 5 layers of the body) can be purified -

1. Annamaya kosh (Food Layer) - Yama, Niyama, Asana 
Dr. Ravi Shankar Mourya ${ }^{1}$, International Journal of Ayurvedic\& Herbal Medicine 7(6) Nov.-Dec. 2017 (3030-3033)

2. Pranamaya kosh (Vital Air Layer) - Pranayama

3. Manomaya kosh (Mental \& Emotional Layer) - Pratyahara \& Dharna

4. Vigyanmaya kosh (Intellect Layer) - Dhyana

5. Anandmaya kosh (Spiritual Layer) - Samadhi

\section{CONCEPT OF HEALTH \& YOGA :-}

Loving and enthusiastic you are Acc ording to WHO Definition of Health: "Health is a complete state of physical, mental, social and spiritual wellbeing and not merely absence of disease or infirmity." And this is where Yoga helps; Postures, Pranayama (Breathing techniques) and meditation are a holistic fitness package.

\section{MAJOR BENEFITS OF YOGA POSTURES :-}

Yoga has so many tremendous benefits that can't even be evaluated.

- Glowing skin

- Peaceful mind

- Good Physical, Mental, Social \& Spiritual health

- Weight loss

- Improved Immunity

- Stress relief

- Awareness

- Better concentration

- Increased energy

- Flexibility

- All round fitness and so on-whatever you may be looking for, yoga has it offer.

\section{BENEFICIAL ASANAS IN LIFE THREATENING DISEASES:-}

Almost all Yoga postures and some specifics for specific disorders are very useful for getting rid off diseases. Such as-

Diabetes:- It is one of the major health problems prevailing in country. We might be able to get rid of this disease or not but with the help of Yoga, it can be controlled. Major effective Asanas for curing Diabetes-

- Gomukhasana

- Vakrasana

- Mandukasana ... etc.

Due to the increasing ratio of diabetic patients, even the $1^{\text {st }}$ International Yoga Day ( $21^{\text {st }}$ June 2015) was mainly focused on "Diabetes and Yoga".

Obesity: - Are the best Yoga Asanas for managing obesity.

- Sun salutations (Surya Namaskar)

- Kapalbharti

- Bow pose

- Cobra pose... etc. 
Dr. Ravi Shankar Mourya ${ }^{1}$, International Journal of Ayurvedic\& Herbal Medicine 7(6) Nov.-Dec. 2017 (3030-3033)

Bronchial Asthma:- Major effective Asanas for curing Bronchial Asthma are -

- Savasana

- Utthasana

- Chakrasana

- Matsyasana (Fish pose)......etc.

Low Backache - LBA :- Major effective Asanas for curing Low Backache -

- Tadasana

- Chakrasana

- Dhanurasana

- Matsyasana (Fish pose).....etc.

\section{ABOUT THE LOGO :-}

Its logo itself is a reflection of its enormous deeds.

$\checkmark$ Folding of both hands in the logo symbolize Yoga, the union.

$\checkmark$ Brown leaves symbolize Earth element, Green leaves- Nature, Blue-the Water, Brightness-the Fire and the Sun- Source of Energy \& Inspiration.

$\checkmark$ The logo reflects harmony and peace for Humanity, which is the essence of Yoga. Hence, Yoga unite the body, mind and soul into one harmonious world through balance of Action, Emotion and Intelligence.

\section{CONCLUSION :-}

Someone may ask- Why do I do Yoga? Well answers are many, shall we say-Yoga-My Fitness Mantra, My weight loss formula, My mind soother and many more. Yoga practice helps to develop the body and mind. Brings a lot of health benefits. But it is important to learn postures under guidance of trained Yoga teacher. Various Yoga center's like "ISHA Centers" are established worldwide for training YOGASANAS.

Researches and studies confirm what our ancient science has been preaching all Along-Incredible Health effects of Yoga.

The very heart of Yoga practice is Abhyasa. So keep practice and make yourself sound.

\section{"PRACTICE YOGA, GAIN MOKSHA"}

\section{REFRENCE :-}

1. Saraswati Swami Satyananda Asana Pranayama Mudra Bandha, 2008, $4^{\text {th }}$ edition. Yoga Publication Trust Munger, Bihar, India.

2. Samgandi Dr. Kashinath \& Jagrati Sharma ,Swasthvarth Sudha , Ayurved Sanskrit Hindi Pustak Bhandar Jaipur

3. Agrawal Dr. Sarvesh Kumar, Swasthvarth Vigyana, Chokhambha orientaliya Varanasi

4. https:// www.nhp.gov.in

5. https:// www.artofliving.org 